Revista de BIOLOGía TROPICAL

\title{
Climate of an oceanic island in the Eastern Pacific: Isla del Coco, Costa Rica, Central America
}

\author{
Eric J. Alfaro ${ }^{1,2,3}$, Hugo G. Hidalgo ${ }^{1,2}$
}

1. Center for Geophysical Research, University of Costa Rica, 11501-2060 San José, Costa Rica; erick.alfaro@ucr.ac.cr, hugo.hidalgo@ucr.ac.cr

2. School of Physics, University of Costa Rica, 11501-2060 San José, Costa Rica.

3. Marine Sciences and Limnology Research Center (CIMAR), University of Costa Rica, 11501-2060 San José, Costa Rica.

Received 06-III-2015. C Corrected 05-V-2015. Accepted 27-V-2015.

\begin{abstract}
Studies of atmosphere-ocean interaction in the Pacific of Costa Rican are scarce. To identify oceanographic systems that may be influencing climate near Cocos Island (Eastern Tropical Pacific Seascape) we conducted six scientific expeditions between 2007 and 2012. Two automated weather stations were set near Chatham and Wafer bays during the expeditions. Data included records from National Meteorological Institute, Global Precipitation Climatology Project (GPCP) and Extended Reconstructed Sea Surface Temperature (ERSST). The climate is typical of the Eastern Tropical Pacific. Its seasonality is driven by precipitation variability associated with meridional migration of the Intertropical Convergence Zone. The seasonal cycle has two peaks, in May and July, a relative minimum between them in June, and the absolute minimum in February. Most of the precipitation is recorded from April to November. Most rain events have short duration and low intensity. An SST trend was observed from January 1854 to December 2013, coherent with regional warming temperature observations. From 1998 to 2013 there were changes in distributions of almost all meteorological parameters. The combination of these factors resulted in higher evapotranspiration values through the daily cycle, especially during the night time. Precipitation $(\mathrm{P})$ positive anomalies tended to be associated with positive air surface temperature (AST) and SST anomalies and negative global radiation (GR) anomalies. Negative P anomalies tended to be associated with negative AST, SST and positive GR anomalies. Relative humidity (RH) negative anomalies tend to be associated with positive wind speed (WS) anomalies, and the WS effect is opposite for positive RH anomalies. During the cold Niño 3 condition of October 2007, negative P, AST, SST and RH anomalies were observed in concordance with positive WS and GR anomalies, in agreement with the conceptual model of climate system response at Isla del Coco to cold ENSO conditions. Rev. Biol. Trop. 64 (Suppl. 1): S59-S74. Epub 2016 February 01.
\end{abstract}

Key words: Isla del Coco, Cocos Island, Costa Rica, Eastern Tropical Pacific, climate.

Even though atmosphere-ocean interaction is a key point in oceanography research (e.g. Fiedler, \& Lavin-Peregrina, 2006; LavinPeregrina et al., 2006), studies related to atmospheric aspects in this specific part of the Costa Rican Eastern Tropical Pacific Seascape (ETPS) are still scarce (Cortés, 2012a,b; 2014). Henry Pittier pointed out the importance of Isla del Coco for geophysical research at the end of the 19th century (Pittier, 1898; Alfaro, 2008). He recognized that to understand the
Pacific Ocean's climate, it was very important and practical for Costa Rica to establish an observatory on Isla del Coco.

In spite of the importance of meteorological monitoring, measurements have been scattered in space and time around this site, mainly because of its distance from the continent, along with the associated costs for the expeditions and maintenance of permanent stations. Although these short records of meteorological variables allowed the description of main 
climatic aspects of the island (e.g. Fernández, 1984; Herrera, 1985; Alfaro, 2008; QuirósBadilla, \& Alfaro, 2009), Cortés, Morales, Alfaro, Lizano \& Acuña (2010) recommended the reinstallation of an automated meteorological station at Isla del Coco by the Costa Rican National Meteorological Institute (IMN for its name in Spanish). This recommendation was attended and meteorological measurements started again in August 2010, finishing a gap since November 2002.

Summarizing the Isla del Coco basic climate characterization, Alfaro (2008) and Quirós-Badilla \& Alfaro (2009) observed that January, February and March (JFM) had the lowest precipitation accumulations, followed by an intense rainy season between April and December, with showers reported mainly during the afternoon. The warmest temperatures were observed in JFM, showing a small decrease from June to December. JFM also had the highest net radiation values and the lowest relative humidity $(\mathrm{RH})$ and wind speed (WS) values near noon hours. The air in motion toward equatorial regions caused by the pressure gradient between the tropics and subtropics is known as the trade winds and is observed as northeasterlies in the northern hemisphere and southeasterlies in the southern hemisphere due to the effect of the Coriolis acceleration (Amador, Alfaro, Lizano, \& Magaña, 2006). The trade winds converge toward low latitudes (Hastenrath, 1991), carrying moisture and forcing the air into a region of strong upward motion, the Inter-Tropical Convergence Zone (ITZC; Amador et al., 2006). According to Amador et al. (2006), the low level zonal circulations observed over the eastern tropical Pacific are part of the trade wind system at low latitudes and present regions of convergencedivergence that are very important for defining ocean surface mean properties associated with the SST distribution and the warm pool region. The trade winds constitute an important meridional energy and moisture exchange mechanism (as part of the low level branch of the Hadley cell) that determines to a great extent the precipitation distribution in the region, i.e., the
ITCZ. In general, seasonal variations at Isla del Coco were observed to be mainly associated with the meridian migration of the ITCZ; as the island is under its direct influence from boreal Spring to Autumn. Results showed that warm ENSO events modulates that ITCZ migration and tend to be associated with above normal precipitation and temperature seasons at Isla del Coco and vice versa. The eastern Pacific warm pool, a region of warm water southwest of Mexico, is a region of relatively weak zonal winds, potential convective activity and tropical system development (Amador et al., 2006). Its effects on Isla del Coco climate are unknown. A more detailed examination of the relevant atmospheric forcing, on annual and seasonal time scales, in the eastern tropical Pacific region is presented by Amador et al. (2006).

The first objective of this work was to present the meteorological measurements collected during the scientific expeditions from 2007 to 2012 and to compare these observations with climate values from weather stations that operated on the island. These comparisons through graphic anomalies can also be useful in the interpretation of results for the other project components, especially because no meteorological station functioned permanently at the island during the 2007-2010 expeditions. A second objective was the analysis of the new IMN records and the comparison of them with previous ones, specifically between 2010-2013 and 1998-2001. This can be useful in trend detection and homogeneity using time series analysis, and compared with gridded data sets in the ETPS area context.

\section{MATERIALS AND METHODS}

The use of automated weather stations allowed making meteorological measurements at Isla del Coco, Costa Rica, located in the ETPS. The stations were set up at Chatham $\left(5^{\circ} 32^{\prime} 51^{\prime \prime} \mathrm{N}, 87^{\circ} 02^{\prime} 43^{\prime} \mathrm{W}, 142\right.$ m.a.s.1.) and

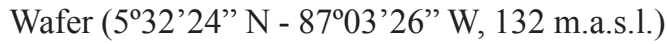
bays. Data were registered every $5 \mathrm{~min}$ and hourly values were generated. Variables analyzed in this work included hourly-accumulated 
precipitation $(\mathrm{P})$ and global radiation (GR) defined as the total incoming radiation, along with average air and sea surface temperature (AST and SST respectively), RH and WS. Measurements were recorded during the expeditions on: October 12-17, 2007, April 5-11, 2008, March 1-6, 2009, April 22-27, 2010, July 2-8, 2011 and March 15-21, 2012. Davis weather stations, Vantage Pro Plus/Vantage Pro2 Plus type, were used during all the expeditions except in October 2007 in which a Campbell, CR10X type was used in Chatham Bay. No measurements were collected in Wafer during this first expedition. Additionally, Kestrel $4500 \mathrm{NV}$ portable stations were installed on the ship anchored at Chatham Bay during the last five expeditions.

Hourly records were obtained from the IMN weather station located in Chatham Bay

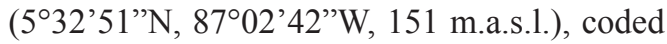
as 200002 . The records obtained were divided in two parts. First, from 11:00 August 30, 1998 to 18:00 November 1, 2002, and second, from 18:00 August 30, 2010 to 16:00 September 9, 2013. For comparison with the weather stations installed during the campaigns, monthly average values corresponding to the month of the expedition from these IMN records were calculated for the same atmospheric variables obtained during the campaigns. Additionally, monthly average values when IMN data were available during the last two expeditions and the whole period of record averages were calculated for these same variables. Seasonal cycles of dew point temperature and sea level pressure (SLP) were also analyzed for the second part of the record in this station, as they were not available for the first part.

Additionally, the one or five minute records of a GPS automated weather station, were obtained from the COCONET project (http://facility.unavco.org/gsacws/gsacapi/site/ search?site.group=COCONet, Protti, González, Freymuller, \& Doelger, 2012) and hourly data were produced from them, covering from 14:00 May 18, 2011 to 17:00 September 19, 2013. The station was coded as CocosIsl CRI2011 and located in Wafer Bay (5'32'40"
N - 87 03 '20" W, 11 m.a.s.1.). Data can be downloaded from http://www.unavco.org/ data/gps-gnss/data-access-methods/dail/raw rinex_by_download.php?sid=5588\&parent link $=$ Permanent\&pview $=$ original. As it was done for the IMN station, the monthly average corresponding to the same month of the expedition and the entire period averages were calculated for comparison, except for GR, which was not observed at this site. Seasonal cycles for maximum and minimum temperature (Tmax and Tmin) were also analyzed for this station record.

The GPS-COCONet data at temporal resolutions of one and five minutes were used to determine the typical storm duration and intensity. For some of the analyses a comparison between the meteorological variables for an early period (September 1, 1998 to August 31, 2001) and a later period (September 1, 2010 to August 31, 2013) was performed using the data from the IMN, but filling the missing data using the GPS data by establishing relationships between the percentiles of the datasets during a common period. The comparison between the periods during the rainy and dry seasons was done using cumulative density functions and a Kolmogorov-Smirnov test in order to determine if the data from both periods could be considered to have the same distribution or not.

The hourly measurements of net radiation, AST, RH and WS from the IMN data (filled with GPS) were used to compute the reference evapotranspiration (ETo) for the early and late periods described above, with the objective to detect differences between them. Reference evapotranspiration is a hydrological term, it is referred to the evapotranspiration for a hypothetical grass reference crop with an assumed crop height of $0.12 \mathrm{~m}$, a fixed surface resistance of $70 \mathrm{sm}^{-1}$ and an albedo of 0.23 .

Precipitation data from the Global Precipitation Climatology Project (GPCP; Adler et al., 2003), version 2.2, were provided by the National Oceanographic and Atmospheric Administration (NOAA), Office of Oceanic and Atmospheric Research, Earth System 
Research Laboratory, Physical Sciences Division, Boulder, Colorado, United States, from their website (http://www.esrl.noaa.gov/psd/). The data are combinations of satellite and raingauge sources and were available from January 1979 to October 2013. The spatial resolution of the data is $2.5 \times 2.5^{\circ}$. The grid-point centered at $6.25^{\circ} \mathrm{N}-86.25^{\circ} \mathrm{W}$, covering the area $5-7.5^{\circ} \mathrm{N}-85-87.5^{\circ} \mathrm{W}$, was studied and also the precipitation average grid point differences composites between 2010-2013 and 1998-2001 for April-November and December-March seasons. The area that covers the composites was $3-22^{\circ} \mathrm{N}-73-97^{\circ} \mathrm{W}$.

SSTs were obtained from four sources during the expeditions. Surface values $(<2 \mathrm{~m}$ deep) measured with the conductivity, temperature, and depth of the ocean instrument or CTD (Lizano, \& Alfaro, 2014) and Niskin bottles using an YSI sensor (Acuña-González, GarcíaCéspedes, Gómez-Ramírez, Vargas-Zamora, \& Cortés, 2008) from oceanographic stations around the island. The values were also measured in the current meter anchored at Wafer Bay $(<2 \mathrm{~m}$ deep) during the first expedition (Lizano, \& Alfaro, 2004). For comparison the Extended Reconstructed Sea Surface Temperature (ERSST) (Smith, Reynolds, Peterson, \& Lawrimore, 2008) dataset was included. It was provided by the International Research Institute for Climate and Society, The Earth Institute, Columbia University, New York, United States, from their website (http://iridl.ldeo.columbia. edu/). ERSST is a global monthly sea surface temperature analysis derived from the International Comprehensive Ocean-Atmosphere Data Set with missing data filled in by statistical methods. This monthly analysis begins in January 1854 continuing to December 2013. The newest version of ERSST (3b) used in this work is optimally tuned to exclude undersampled regions for global averages and does not include satellite data. For this data set the long-term monthly average values corresponding to the respective months of the expedition and the specific monthly values during the expeditions were also extracted among the whole period of record average for the grid point centered at $6^{\circ} \mathrm{N}-88^{\circ} \mathrm{W}$ which covers the area $5-7^{\circ} \mathrm{N}-87-89^{\circ} \mathrm{W}$. Composites of average grid-point differences were estimated, similar to the gridded precipitation analysis described previously using Adler et al. (2003) data. The spatial resolution of the data is $2 \times 2^{\circ}$.

Finally, the Tropical Rainfall Measurement Mission (TRMM) (Huffman et al., 2007) data were used in a precipitation trend analysis. TRMM is a joint mission between the National Aeronautics and Space Administration (NASA) and the Japan Aerospace Exploration Agency (JAXA). In this study, the 3B42 estimates version 6 were chosen. These estimates correspond to a 3-hourly average centered at the middle of each 3-hour period (i.e., 0Z, 3Z, 6Z, 9Z, 12Z, 15Z, 18Z, and 21Z). The final 3B42 product data are available at $0.25 \times 0.25^{\circ}$ spatial resolution extending from $50^{\circ} \mathrm{S}-50^{\circ} \mathrm{N}$. For the present study, the period 1998-2009 was used. In order to transform the satellite precipitation data into a daily frequency, it was necessary to merge the 3-hourly data, considering the local time.

\section{RESULTS}

Precipitation seasonal and daily cycles are shown in Figure 1 for IMN and GPS-COCONet weather stations. Figure 1A incorporated data collected after August 2010 and agreed in general terms with previous results of Alfaro (2008) and Fernández (1984). About $88 \%$ of the precipitation was recorded from April to November, with showers during the afternoon. The seasonal cycle had two peaks in May and July with more than $19 \mathrm{~mm} \mathrm{day}^{-1}$ and a relative minimum between them in June diminishing to 15-16 $\mathrm{mm} \mathrm{day}^{-1}$, with the absolute minimum in February, $<4 \mathrm{~mm}$ day $^{-1}$. The daily cycle also exhibited a secondary maximum in the early morning around sunrise. Data records used to calculate the seasonal and daily cycles (Fig. 1B) were considerable less than those used in Fig. 1A, but the figure was included for comparison. Absolute maximum and minimum values in the seasonal cycle were also present in July and February respectively in the data 

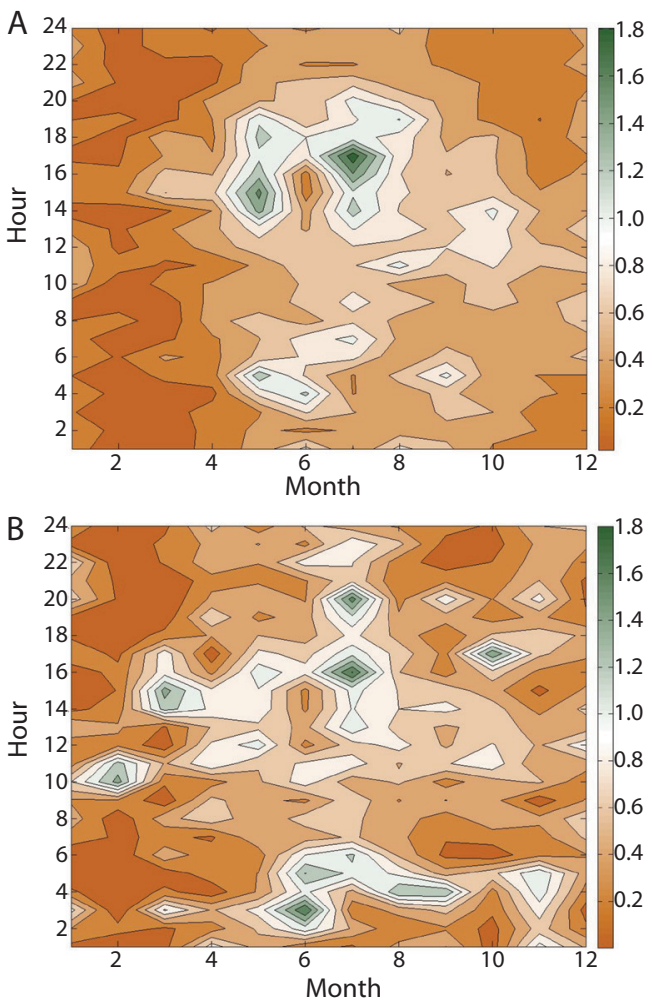

Fig. 1. Seasonal (horizontal axis) and daily (vertical axis) precipitation (mm hour ${ }^{-1}$ ) cycles of the automatic a) IMN and b) GPS weather stations in Chatham and Wafer Bay, respectively.

from this GPS weather station; and its daily cycle also exhibited a secondary maximum around sunrise, with most of the showers in the afternoon.

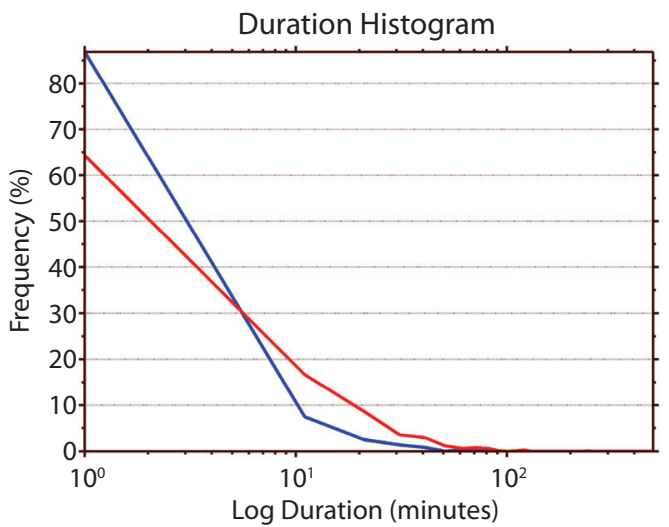

GPS data can be used to characterize showers observed at Isla del Coco. Figure 2 shows histograms of duration and intensity using one and five minute time resolutions. They reflect processes associated with short-lived events of low intensity values, most probably a reflection of events originated from tropical convection (Alfaro, 2008).

Because of the temporal resolution available for this GPS station, it was possible to characterize seasonal cycles for Tmin and Tmax (Fig. 3). Maxima for both curves were observed in March-April, previous to the AprilNovember rainy season. The mean difference between them was $0.7^{\circ} \mathrm{C}$, and the lower temperatures were observed from July to December. However, variations through the year were less than $2^{\circ} \mathrm{C}$. Conversely, dew point temperature from IMN station is highest in August and lowest in October, with a difference of $2.8^{\circ} \mathrm{C}$ between them (Fig. 3). This variable was not reported previous to 2010. According to Alfaro (2008), this result agreed with a relative minimum and a maximum observed in the WS during those months. Mean values for the three curves observed in Figure 3 were 25.5, 24.8 and $22.2^{\circ} \mathrm{C}$ respectively.

Monthly average SLP for the automated IMN weather station located in Chatham Bay is presented in Figure 4. March and October show the minimum and maximum values, with a difference between them of approximately $2.2 \mathrm{hPa}$. Mean value observed was $1015 \mathrm{hPa}$.

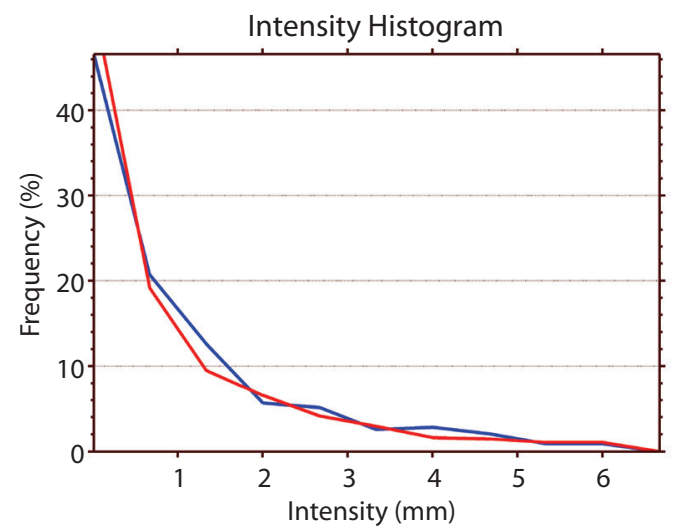

Fig. 2. Duration and intensity of rainfall for data with a resolution of 1 minute (blue) and 5 minutes (red). 


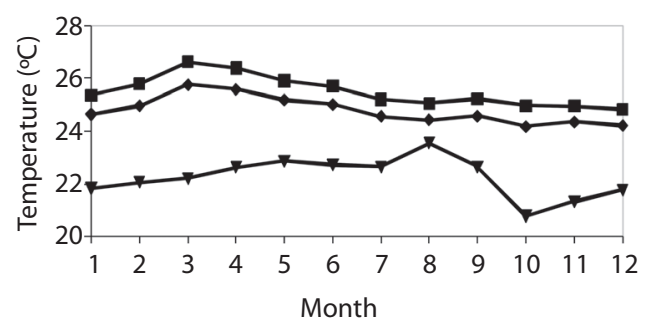

Fig. 3. Diamond (squared) line is for the monthly average of minimum (maximum) temperatures for the automatic GPS weather station in Wafer Bay. Triangle line is dew point temperatures for the automatic IMN weather station in Chatham Bay.

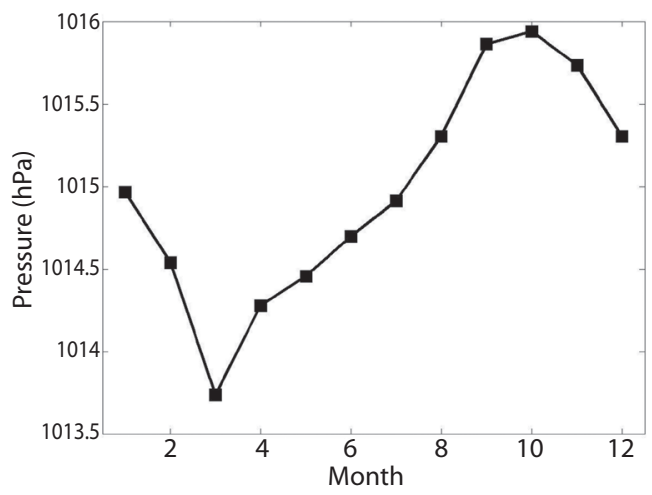

Fig. 4. Monthly average of sea level pressure for the automated IMN weather station in Chatham Bay.

This variable was also not reported previous to 2010, but Fernández (1984) also observed high-pressure values during October-November and the lowest value in March. These values could be related with the meridional ITCZ seasonal migration.

A positive but statistically insignificant precipitation trend was detected for the grid point centered at $6.25^{\circ} \mathrm{N}-86.25^{\circ} \mathrm{W}$, from January 1979 to Oct 2013 (Fig. 5), and for the TRMM data as well. Maldonado \& Alfaro (2012) noticed that Isla del Coco is located in a region with observed negative trends in the North and positive ones in the South, in agreement with the small trend value of Figure 5. This result contrasted with the one obtained for SST in the grid point centered at $6^{\circ} \mathrm{N}$ $88^{\circ} \mathrm{W}$ (Fig. 6), in which a positive statistical significant trend was observed in the long-term record from January 1854 to December 2013. This SST positive trend was observed in other locations near Costa Rica's ETPS (Alfaro et al., 2012; Morales-Ramírez, Lizano, Acuña, Alfaro, \& Gómez, 2015) and was coherent with regional warming temperature observations reported by the IPCC (Bindoff et al., 2013).

Figure 7 shows the mean values measured at Isla del Coco during the expeditions for P, AST, RH, GR, WS and SST. When climate norms from IMN, GPS and Smith et al. (2008) data were compared with measurements from the first expedition (October 12-17, 2007), it was observed that this expedition presented negative anomalies for P, AST and SST (except for the current meter's value located in Wafer) and positive anomalies for GR and WS. October 2007 presented a negative Niño 3 SSTA index anomaly of $-1.20^{\circ} \mathrm{C}$ (using data from http://www.cpc.ncep.noaa.gov/data/indices/ersst3b.nino.mth.81-10.ascii). The tropical Pacific Niño 3 index area $\left(5^{\circ} \mathrm{S}-5^{\circ} \mathrm{N}, 90-150^{\circ}\right.$ $\mathrm{W})$ is the nearest to Isla del Coco and was used in the ENSO variability study (Quirós-Badilla, \& Alfaro, 2009). Anomalies recorded during the first expedition agreed with the P, AST and SST behavior expected for cold ENSO conditions, according to Quirós-Badilla \& Alfaro (2009). During the other expeditions, Niño 3 index showed values close to what it is considered ENSO neutral conditions $(-0.5 \leq$ Niño $3 \leq$ $0.5^{\circ} \mathrm{C}$, approximately). The second expedition (April 5-11, 2008) presented positives anomalies for P (except for Wafer station), AST, TSM and WS (except for Chatham station) and negative anomalies for $\mathrm{RH}$ and GR. The third expedition (March 1-6, 2009) presented positive anomalies for $\mathrm{P}, \mathrm{RH}$, WS (except for Chatham) and SST and negative anomalies for AST (except for the measurements in the ship anchored at Chatham Bay) and GR. SST grid point monthly value anomaly was negative during that expedition. The fourth expedition (April 22-27, 2010) presented positive anomalies for P, AST, SST and WS, and negative anomalies for RH (except for the measurements in the ship anchored at Chatham Bay) 


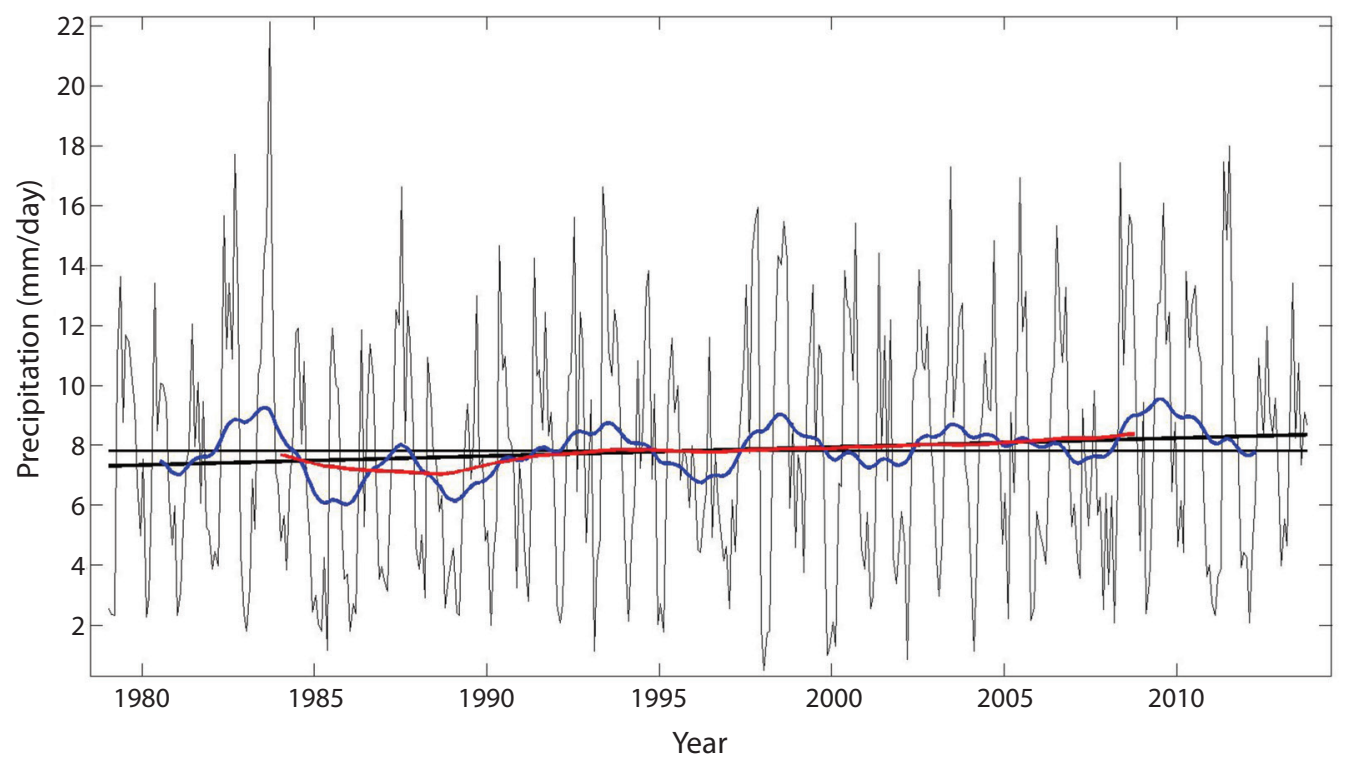

Fig. 5. Monthly precipitation (gray line), average of $7.8 \mathrm{~mm} /$ day (horizontal line). Linear trend (solid black line) is $0.03 \mathrm{~mm} /$ (day*year), with a p-value of 0.12 , measured from January 1979 to October 2013. Grid point centered at $6.25^{\circ} \mathrm{N}-86.25^{\circ} \mathrm{W}$ covering the area $5-7.5^{\circ} \mathrm{N}-85-87.5^{\circ} \mathrm{W}$. Blue and red lines are the smoothed times series using a triangular moving average of 3 and 10 years, respectively. Data from Adler et al. (2003).

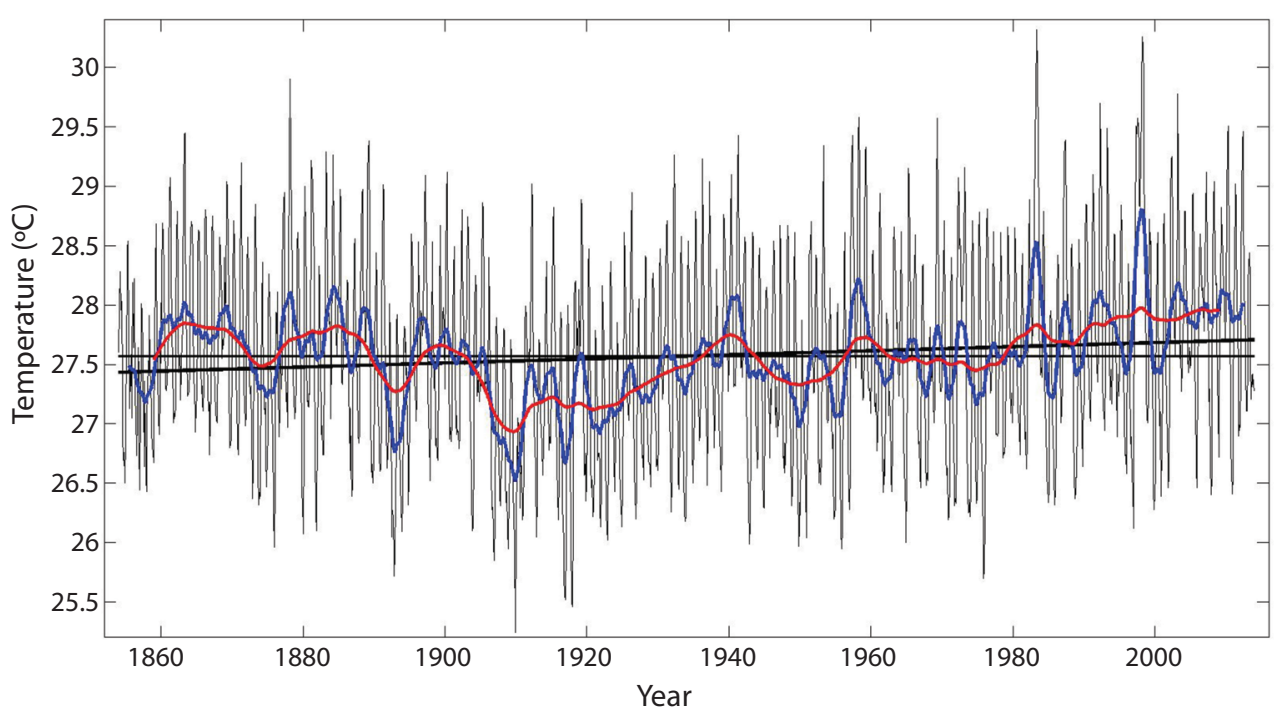

Fig. 6. Monthly sea surface temperatures (gray line), average of $27.6^{\circ} \mathrm{C}$ (horizontal line). Linear trend (solid black line) is $0.0017^{\circ} \mathrm{C} /$ year, with a p-value $<0.01$, measured from January 1854 to December 2013 . Grid point centered at $6^{\circ} \mathrm{N}-88^{\circ} \mathrm{W}$ covering the area $5-7^{\circ} \mathrm{N}-87-89^{\circ} \mathrm{W}$. Blue and red lines are the smoothed times series using a triangular moving average of 3 and 10 years, respectively. Data from Smith et al. (2008) 

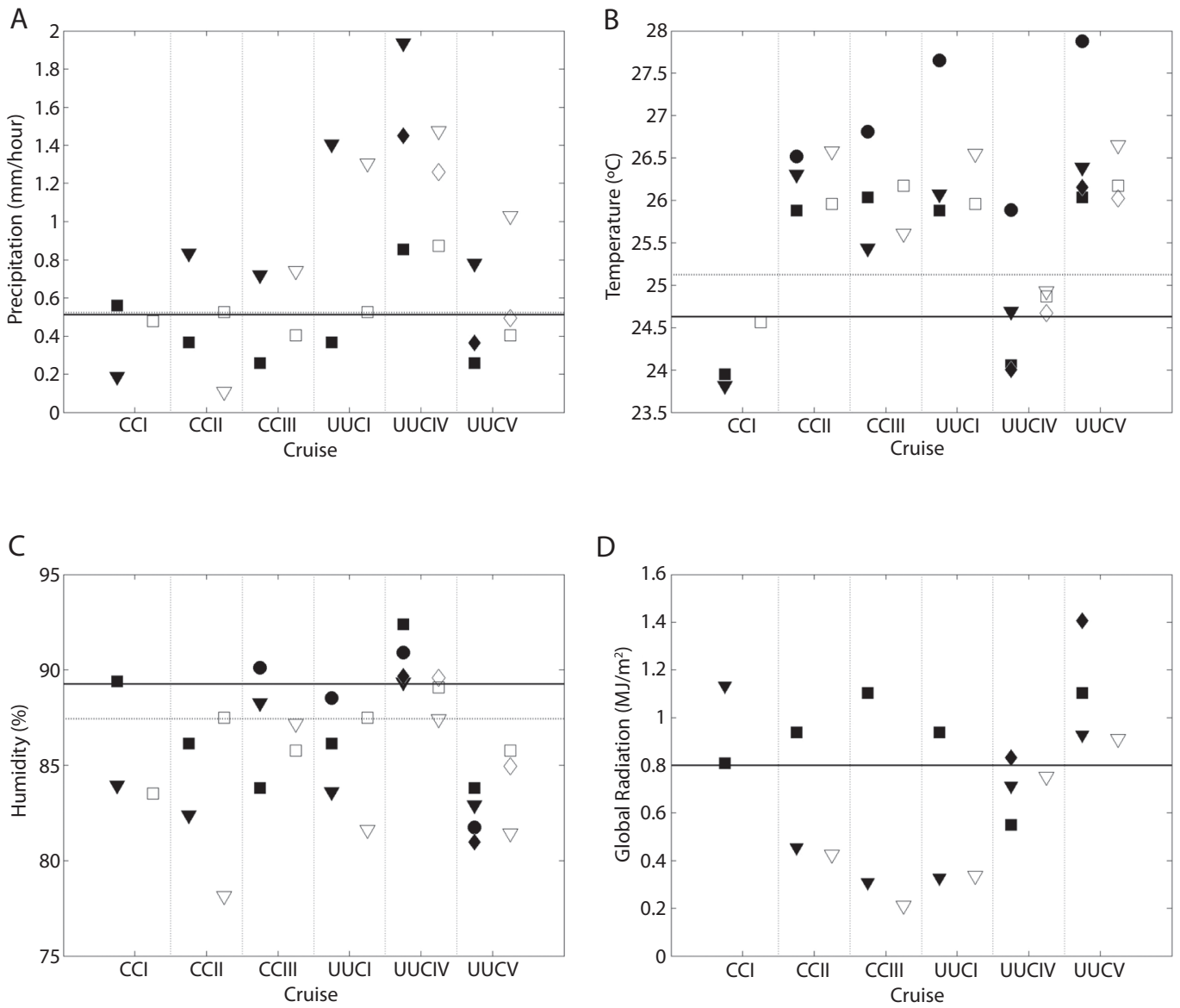

D

E

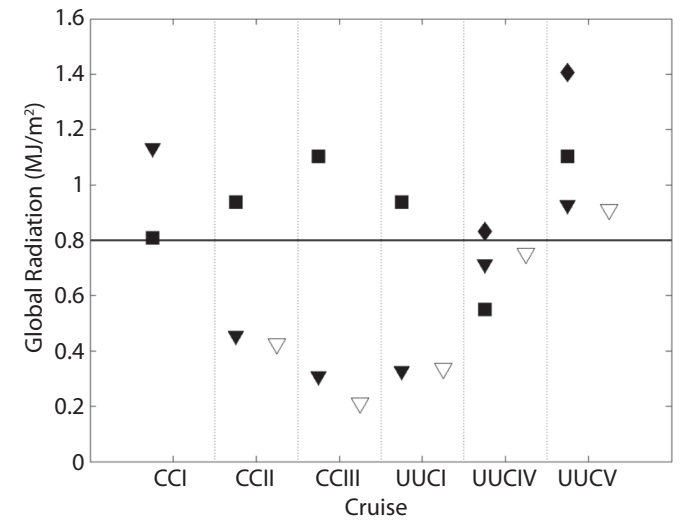

$\mathrm{F}$
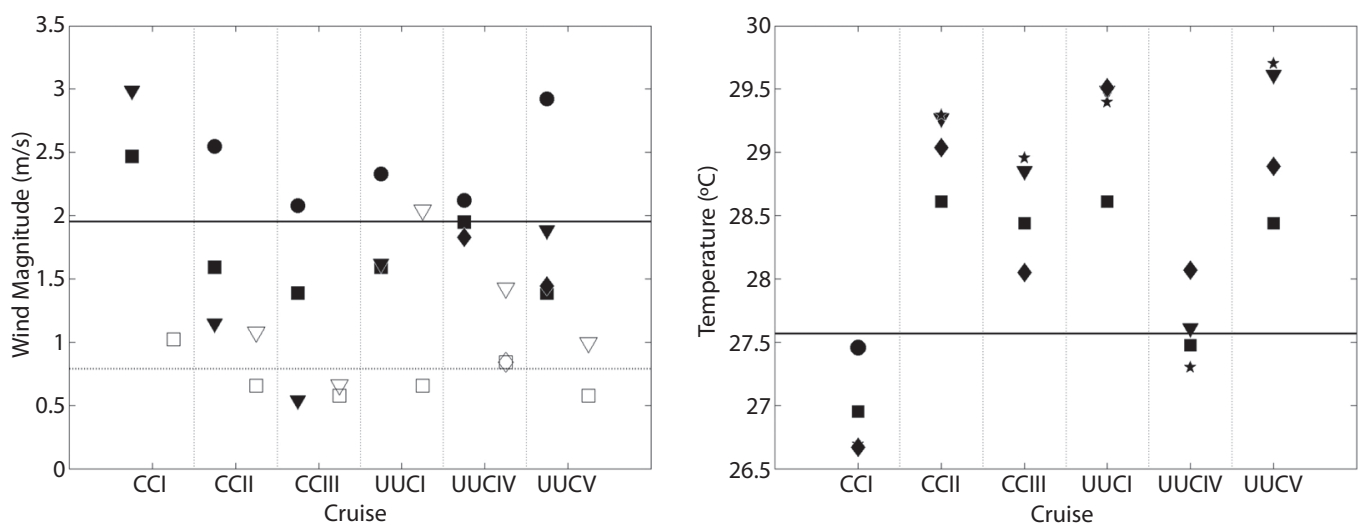

Fig. 7. Mean (A) Precipitation (P), (B) Average Surface Temperature (AST), (C) Relative Humidity (RH), (D) Global Radiation (GR), (E) Wind Speed (WS) and (F) Sea Surface Temperature (SST) values measured at Isla del Coco during the expeditions of October 2007 (CCI), April 2008 (CCII), March 2009 (CCIII), April 2010 (UUCI), July 2011 (UUIV) and March 2012 (UUV). For (A), (B), (C), (D) and (E), black and white triangles are for the values measured at Chatham and Wafer Bay, respectively. Black circles are for the values measured in the ship anchored at Chatham bay. For comparison we include the monthly average values corresponding to the month of the expedition from the Costa Rican NMI and 

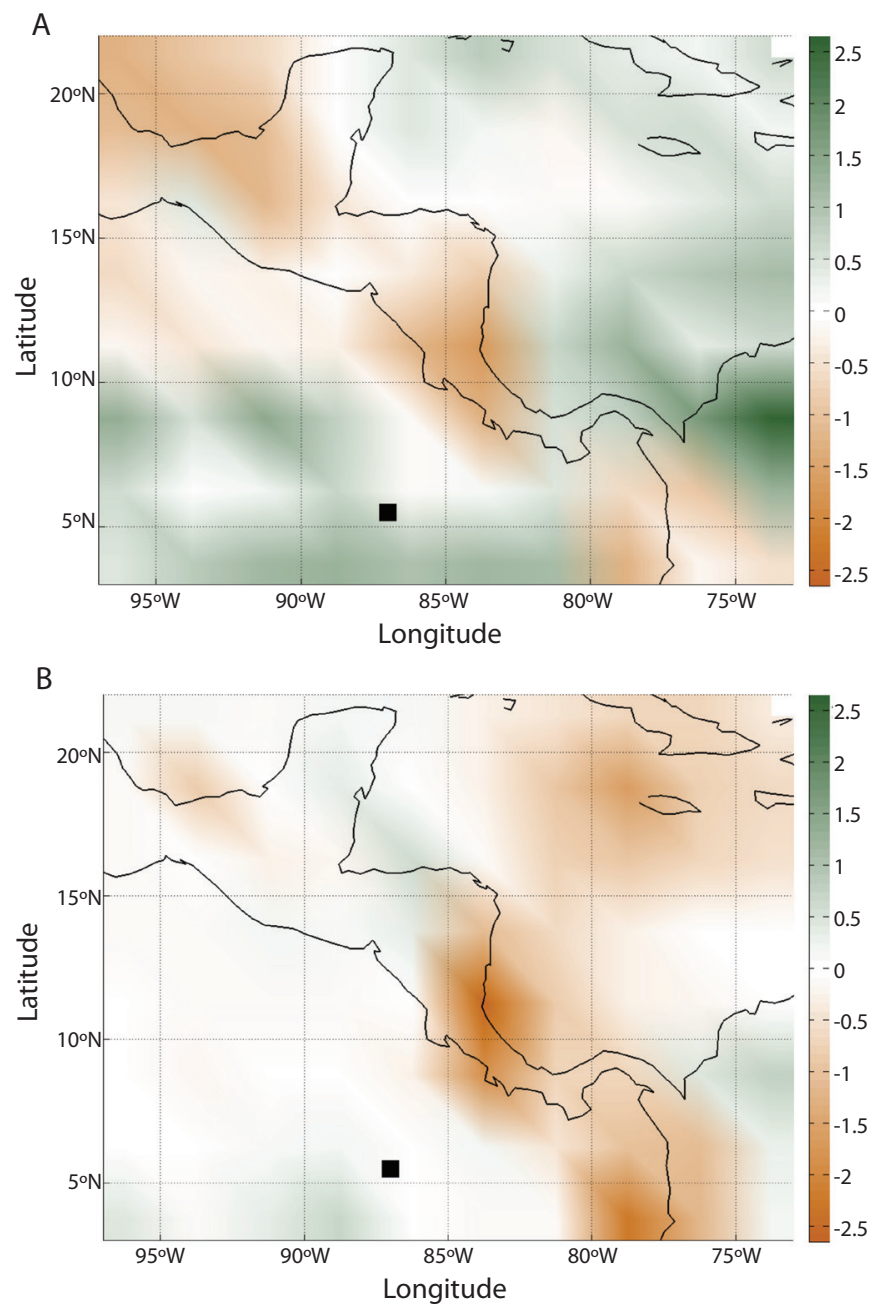

Fig. 8. Precipitation (mm/day) average grid point differences between 2010-2013 and 1998-2001 for (A) April-November and (B) December-March seasons. For the grid point centered at $6.25^{\circ} \mathrm{N}-86.25^{\circ} \mathrm{W}$ covering the area $5-7.5^{\circ} \mathrm{N}-85-87.5^{\circ}$ $\mathrm{W}$, the values are -0.10 and $-0.02 \mathrm{~mm} /$ day, both with p-values $>0.10$. Data from Adler et al. (2003). Black square is Isla del Coco.

and GR. The fifth expedition (July 2-8, 2011) presented positive anomalies for P, AST, TSM (except for the YSI measurements) and WS (no measurements of WS were done in Chatham during this expedition, but monthly values observed in the IMN station were slightly negative when compared to the climate record value for July) and negative anomalies for RH. Average monthly AST values observed in the IMN and GPS stations were slightly lower than

GPS-COCONET stations located in Chatham and Wafer bay (black and white squares respectively); and the monthly average values when data were available when they worked during the expeditions (black and white diamonds respectively). Solid and dashed horizontal lines are the period of record averages available from the NMI and GPS stations respectively. For (F), Black triangles and stars are for the surface values $(<2 \mathrm{~m}$ deep $)$ measured with CTD and YSI equipments at stations around the island. Black circle is for the values measured in the current meter anchored at Wafer bay $(<2 \mathrm{~m}$ deep). For comparison we include the monthly average values of the Smith et al. (2008) record, black squares; the average monthly values for the same record during the expeditions, black diamonds and the record average, solid horizontal line. 

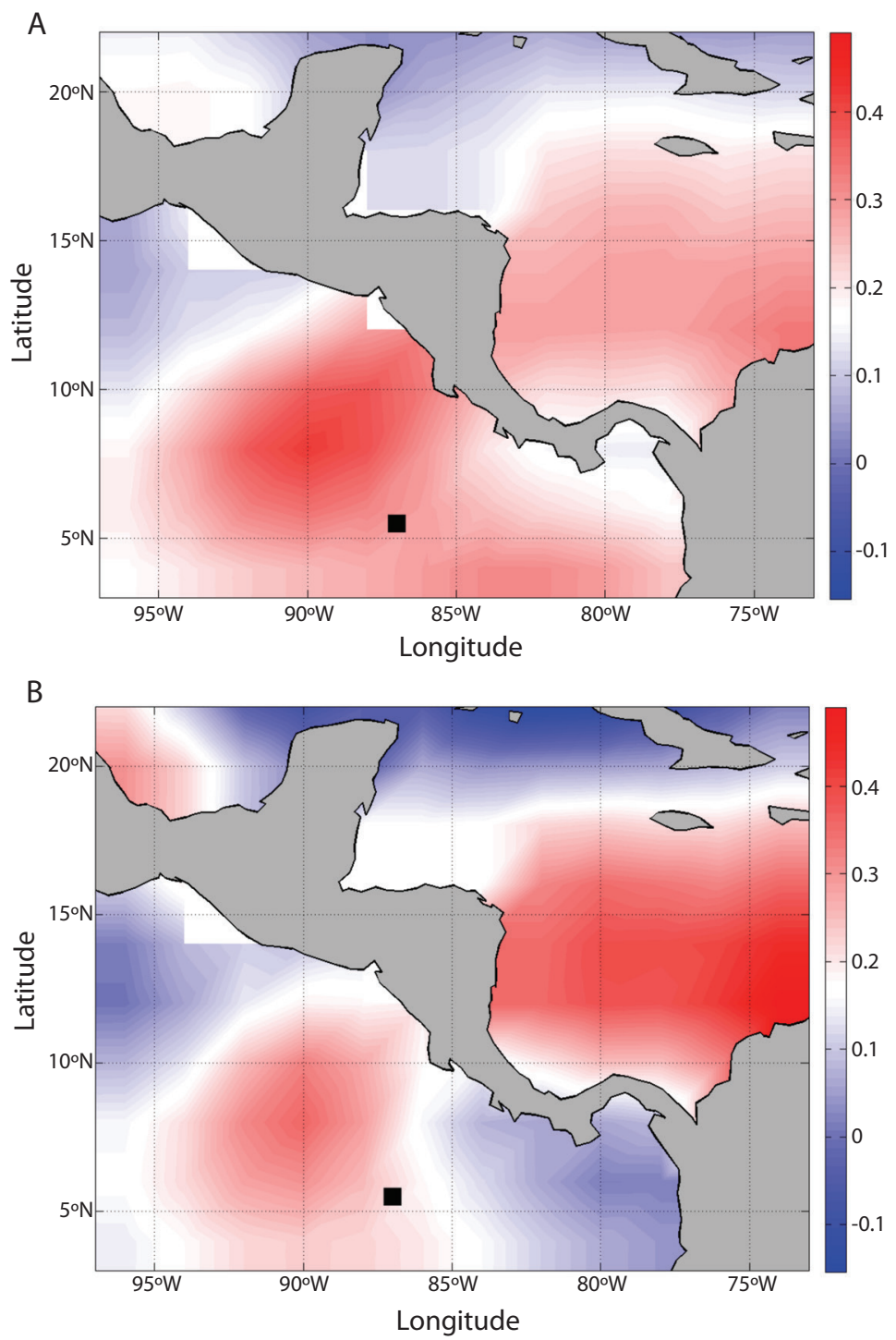

Fig. 9. Sea surface temperature $\left({ }^{\circ} \mathrm{C}\right)$ average grid point differences between 2010-2013 and 1998-2001 for (A) AprilNovember and (B) December-March seasons. For the grid point centered at $6^{\circ} \mathrm{N}-88^{\circ} \mathrm{W}$ covering the area $5-7^{\circ} \mathrm{N}-87-89^{\circ}$ $\mathrm{W}$, the values are 0.32 and $0.25^{\circ} \mathrm{C}$, both with p-values $>0.10$. Data from Smith et al. (2008). Black square is Isla del Coco.

climate norms and RH value slightly higher in the GPS station. The March 15-21, 2012 expedition presented positive anomalies for P, AST, SST and WS and negative anomalies for RH and GR. Average monthly AST values observed in the GPS station were slightly lower than climate ones.

In agreement with the two periods that the IMN station worked, the precipitation and
SST average grid-point differences between the years 2010-2013 and 1998-2001 in the area $3-22^{\circ} \mathrm{N}-73-97^{\circ} \mathrm{W}$ for April-November and December-March seasons were calculated (Figs. 8 and 9) (data from Adler et al., 2003 and Smith et al., 2008). Precipitation and SST differences for the grid-point that covers Isla del Coco were not statistically significant in all cases. For precipitation, the island is located 
in a region of transition between negative differences in the northeast and positive ones in the southwest, especially during the AprilNovember season and over the Central American isthmus (Fig. 8A). The region of negative differences over the Chocó, one of the rainiest places on the earth is notorious (Amador et al., 2006). Figure 9 shows that Isla del Coco is embedded in a broad region of positive SST differences during April-November, and in a transition area between positive values in the northwest and negative ones in the east. In both seasons, the Caribbean Sea showed a broad area of positive differences.

Figure 10 compares the CDFs for the same (previously defined) periods recorded at the IMN station in Chatham. There was no difference in $\mathrm{P}$ during April-November, but it was drier for December-March as in Figure 8. In agreement with Figure 9, warmer values were more frequent for the late period in both seasons, and during this period lower values for RH and WS were more frequent. Southwest winds were more frequent in April-November, but Southeast ones were more frequent in December-March when two periods were compared. Higher net radiation values were more frequent also in the late period, especially during April-November. The combination of those factors described previously resulted in higher reference evapotranspiration (ETo) values through the daily cycle (Fig. 11), especially during night-time. The ultimate causes of the increase in ETo during the night are still unknown, but they could be related to changes in RH and WS during those hours.

\section{DISCUSSION}

Isla del Coco showed a climate regime typical of the ETPS. Its seasonality is driven by precipitation variability associated with the meridian migration of ITCZ (Amador et al., 2006). The seasonal cycle had two precipitation peaks, May and July, and a relative minimum between them in June, with the absolute minimum during February. Most of the precipitation was recorded from April to November, with showers usually during the afternoon as it was identified in Alfaro (2008) (Fig. 1). There are many short-duration rain events with low intensity (Fig. 2). Interannual precipitation variability was driven by ENSO, in which Niño 3 region had an important role modulating the ITCZ migration (Quirós-Badilla, \& Alfaro, 2009). This issue modulated also the interannual AST and SST variability in which normally Niño 3 warm and cold events tended to be associated with positive and negative $\mathrm{P}$, AST and SST anomalies. A non-significant statistically precipitation trend was detected for the grid point centered at $6.25^{\circ} \mathrm{N}-86.25^{\circ} \mathrm{W}$ (Fig. 5).There was little difference in the daily and seasonal temperature cycles, observing that dew point temperature was driven by WS through the year (Fig. 3). Similar characteristics of the daily and seasonal cycles of SLP were observed (Fig. 4). A positive statistically significant SST trend was observed from January 1854 to December 2013 (using data from Smith et al., 2008) in the grid point centered at $6^{\circ} \mathrm{N}-88^{\circ} \mathrm{W}$ (Fig. 6). This behavior was observed for other locations near Costa Rica's ETPS (Morales-Ramírez et al., 2015; Alfaro et al., 2012) and was coherent with regional warming temperature observations reported by the IPCC (Bindoff et al. 2013). There were changes in the statistical distribution of all variables including ETo, except for $\mathrm{P}$ and net radiation during April to November, when the early and late periods were compared (Figs. 10 and 11). It should be noted that the influence of decadal scale climate variations (e.g. Enfield, \& Mestas-Nuñez, 1999; Mestas-Nuñez, \& Enfield, 1999) could be partially responsible for these fluctuations; but future analysis with more in situ data should be done to confirm these findings.

Local meteorological measurements are also important in multidisciplinary research to properly understand the Isla del Coco oceanographic systems (Cortés, 2008; 2012c), as part of the broader ETPS (Henderson, Rodríguez, \& McManus, 2008). In general terms, the meteorological observations collected during the expeditions to Isla del Coco showed that 
Rainy season (May.-Nov.)
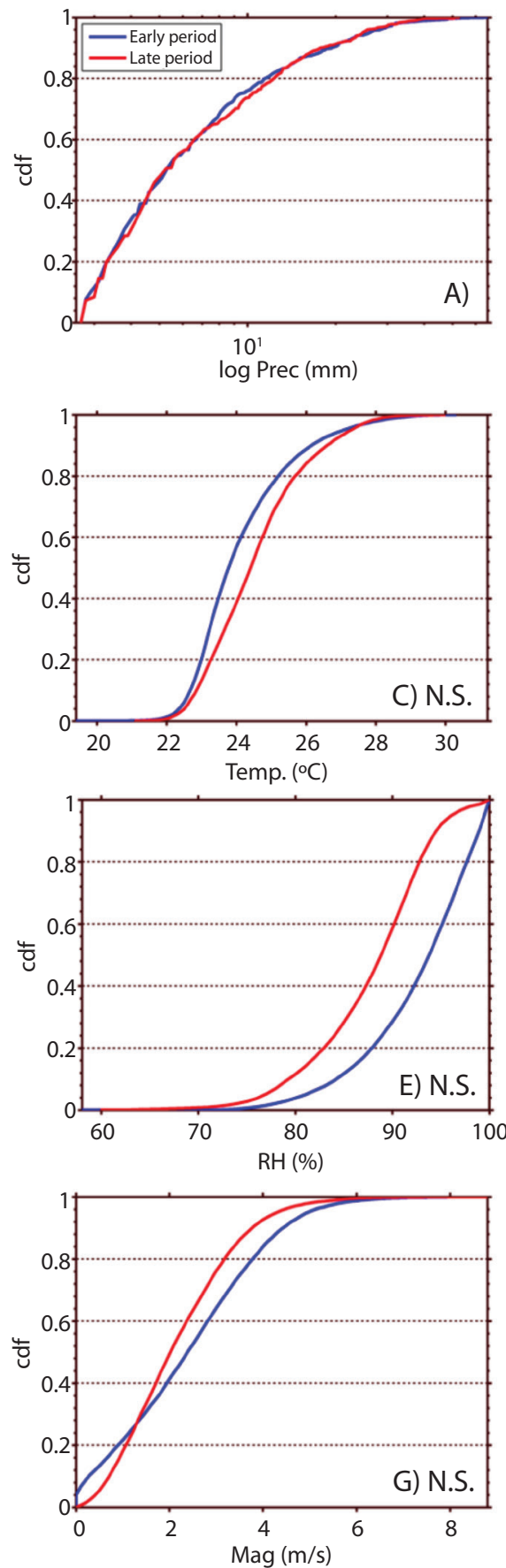

Dry season (Dec.-Apr.)
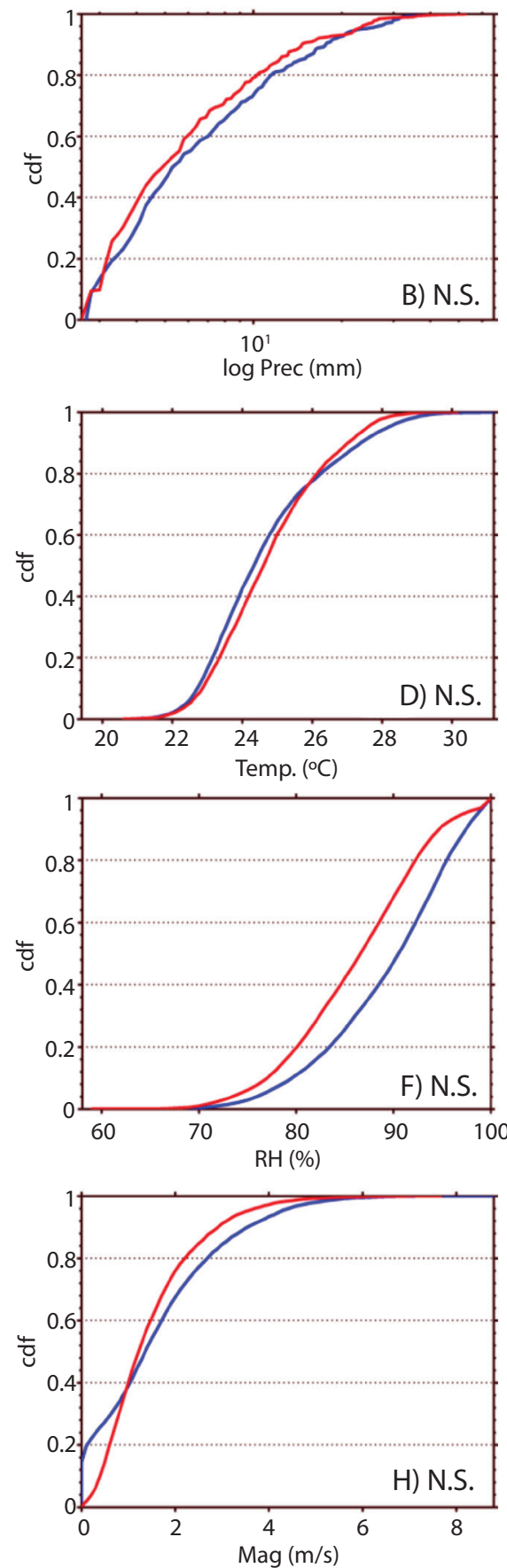

Fig. 10. Empirical cumulative density functions for early (September 1, 1998 to August 31, 2001) and late (September 1,2010 to August 31, 2013) periods for various parameters and seasons. If the data for both periods can be considered to not come from the same distribution according to a Kolmogorov-Smirnov test, the subfigure is labeled with the letter "N.S.". Prec: precipitation, Temp: temperature, RH: relative humidity, Mag: wind speed magnitude, U: zonal wind speed component, V: meridional wind speed component, and Rn: net radiation. 
Rainy season (May.-Nov.)
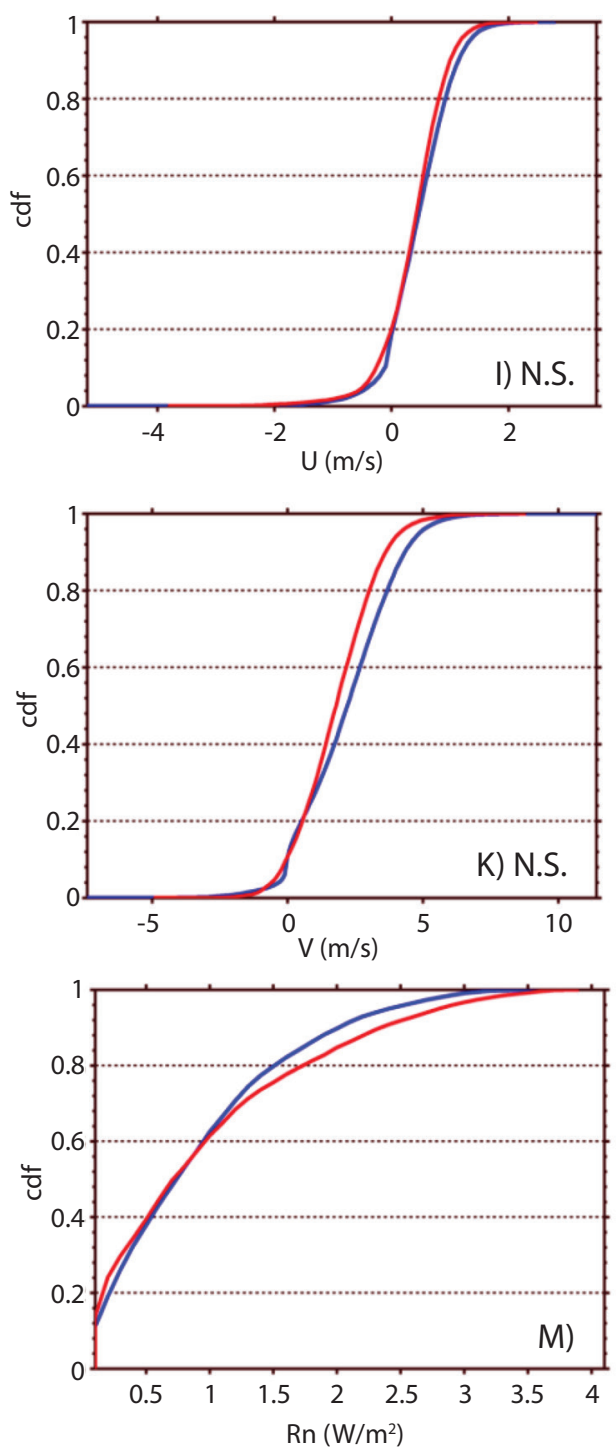

Dry season (Dec.-Apr.)
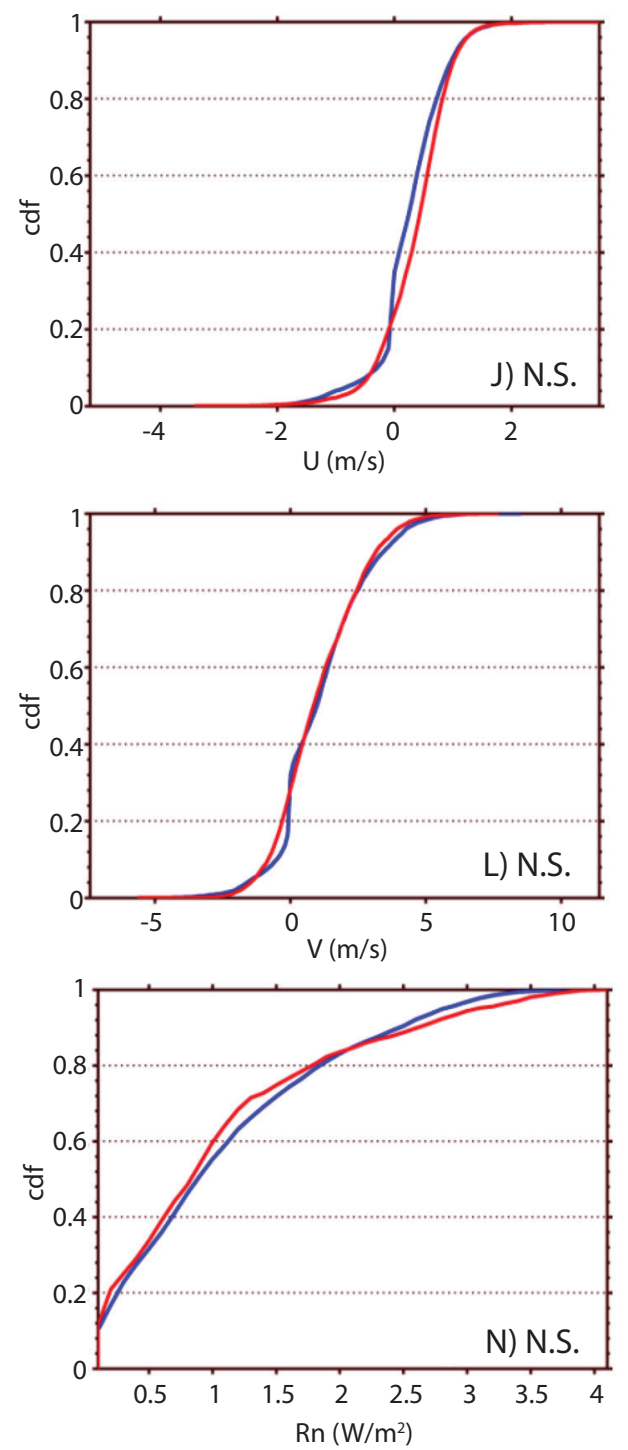

Fig. 10. (Continued) Empirical cumulative density functions for early (September 1, 1998 to August 31, 2001) and late (September 1, 2010 to August 31, 2013) periods for various parameters and seasons. If the data for both periods can be considered to not come from the same distribution according to a Kolmogorov-Smirnov test, the subfigure is labeled with the letter "N.S.". Prec: precipitation, Temp: temperature, RH: relative humidity, Mag: wind speed magnitude, U: zonal wind speed component, V: meridional wind speed component, and Rn: net radiation.

positive (negative) $\mathrm{P}$ anomalies tended to be associated with positive (negative) AST and SST anomalies and negative (positive) GR anomalies. This relationship could indicate that positive (negative) SST anomalies are associated with a warmer (cooler) atmosphere layer above the ocean, associated with more (less) latent heat flux to the atmosphere and more (less) water availability to build precipitation systems. Additionally, RH negative (positive) anomalies tend to be associated with positive (negative) WS anomalies (Fig. 7), WS could 


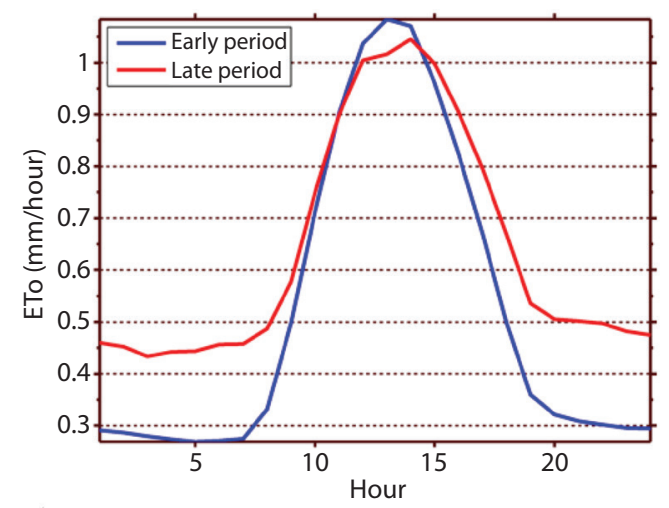

Fig. 11. Diurnal cycle of reference evapotranspiration for early (September 1, 1998 to August 31, 2001) and late (September 1, 2010 to August 31, 2013) periods.

more or less be associated with more or less evaporation and humidity transport away from the island. During the cold Niño 3 condition of October 2007, negative P, AST, SST and $\mathrm{RH}$ anomalies were observed in concordance with positive WS and GR anomalies (Expedition one anomalies in Fig. 7). These results agreed with the conceptual model of climate system response at Isla del Coco to cold ENSO conditions, proposed by Quirós-Badilla \& Alfaro (2009).

Although the island did not show much change in terms of precipitation (Fig. 8), it should be noted that the GPCP data suggested that Costa Rica and parts of Nicaragua, as well as northern Central America and Southern Mexico experienced drier wet-season conditions during the late period compared to the early period. Also, during the dry-season the drying pattern over Costa Rica and Nicaragua was present. It should be noted that the region is influenced by multidecadal climatic mechanisms (e.g. Enfield, \& Mestas-Nuñez, 1999; Mestas-Nuñez, \& Enfield, 1999) and therefore interpreting trends based on differences between short time periods must be done with caution. For example, Hidalgo (2013) found that 1982-2005 trends in precipitation over Central America were inconsistent across different datasets. Precipitation trends (19701999) are in general non-significant, while air temperature trends are more likely significant and mostly positive (Hidalgo et al., in prep.).

\section{ACKNOWLEDGMENTS}

This work was supported by the following CIMAR and CIGEFI, UCR grants: 808-B0-654 (FEES-CONARE), 808-A9-180, 808-A9-902, 808-B5-298, 805-A9-532 (CSUCA-ASDI), 805-B3-600, 805-B3-413 (CI), 805-B0-065, 805-B4-227, 805-B0-810. Thanks to José L. Vargas and Alberto Salazar for all the logistic support during the expeditions. Also to the scientists, rangers and crew participants who collaborated with setting up the meteorological stations.

\section{RESUMEN}

Estudios de la interacción atmósfera-océano en el Pacífico de Costa Rica son escasos. Para identificar los sistemas oceanográficos que pueden estar influyendo el clima cerca de la Isla del Coco (Corredor de Protección Marina del Pacífico Tropical del Este), realizamos seis expediciones científicas entre 2007 y 2012. Dos estaciones meteorológicas automáticas fueron instaladas cerca de las bahías de Chatham y Wafer durante las expediciones. Entre los datos se incluyeron registros del Instituto Meteorológico Nacional, el Proyecto de Climatología Global de Precipitación (GPCP por sus siglas en inglés) y la Reconstrucción Extendida de Temperatura Superficial del Mar (ERSST por sus siglas en inglés). El clima es típico del Pacífico Tropical del Este. Su estacionalidad está impulsada por la variabilidad en la precipitación asociada con la migración meridional de la Zona de Convergencia Intertropical. El ciclo anual de precipitación tiene dos picos en mayo y julio, un mínimo relativo entre ellos en junio, y un mínimo absoluto en febrero. La mayoría de la precipitación se registra de abril a noviembre. La mayoría de los eventos tienen corta duración y baja intensidad. Una tendencia en temperatura superficial del mar (TSM) fue observada de enero 1854 a diciembre 2013, coherente con las observaciones de calentamiento en la región. De 1998 a 2013 hubo cambios en las distribuciones de casi todos los parámetros meteorológicos. La combinación de estos factores resultó en tasas más altas de evapotranspiración a través del ciclo diario, especialmente durante la noche. Anomalías positivas de precipitación $(\mathrm{P})$ tienden a ser asociados con anomalías positivas de temperatura superficial del aire (TSA) y de TSM, y con anomalías negativas de radiación global (RG). Anomalías negativas de P tienden a ser asociadas con anomalías negativas de TSA, TSM y anomalías positivas de RG. Anomalías negativas de humedad relativa 
(HR) tienden a ser asociadas con anomalías positivas de velocidad del viento (VV), y el efecto de la VV es opuesto para anomalías positivas de HR. Durante la condición fría de Niño 3 de octubre del 2007, anomalías negativas de P, TSA, TSM y HR fueron observadas en concordancia con anomalías positivas de VV y RG, de acuerdo con el modelo conceptual de la respuesta del sistema climático en la Isla del Coco ante condiciones frías de ENOS.

Palabras clave: Isla del Coco, Costa Rica, Pacífico Tropical del Este, clima.

\section{REFERENCES}

Acuña-González, J., García-Céspedes, J., Gómez-Ramírez, E., Vargas-Zamora, J. A., \& Cortés, J. (2008). Parámetros físico-químicos en aguas costeras de la Isla del Coco, Costa Rica (2001-2007). Revista de Biología Tropical, 56(Supplement 2), 49-56.

Adler, R. F., Huffman, G. J., Chang, A., Ferraro, R., Xie, P., Janowiak, J., Rudolf, B., Schneider, U., Curtis, S., Bolvin, D., Gruber, A., Susskind, J., \& Arkin, P. (2003). The Version 2 Global Precipitation Climatology Project (GPCP) Monthly Precipitation Analysis (1979-Present). Journal of Hydrometeorology, 4, 1147-1167.

Alfaro, E. J. (2008). Ciclo diario y anual de variables troposféricas y oceánicas en la Isla del Coco, Costa Rica. Revista de Biología Tropical, 56 (Supplement 2), 19-29.

Alfaro, E. J., Cortés, J., Alvarado, J. J., Jiménez, C., Sánchez-Noguera, C., Nivia, J., León, A., \& Ruiz, E. (2012). Clima y temperatura sub-superfical del mar en Bahía Culebra, Golfo de Papagayo, Costa Rica. Revista de Biología Tropical, 60(Supplement 2), 159-171.

Amador, J. A., Alfaro, E. J., Lizano, O. G., \& Magaña, V. O. (2006). Atmospheric forcing in the Eastern Tropical Pacific: A review. Progress in Oceanography, 69, 101-142.

Bindoff, N. L., Stott, P. A., AchutaRao, K. M., Allen, M. R., Gillett, N., Gutzler, D., Hansingo, K., Hegerl, G., Hu, Y., Jain, S., Mokhov, I. I., Overland, J., Perlwitz, J., Sebbari, R., \& Zhang, X. (2013). Detection and attribution of climate change: from global to regional. In T. F. Stocker, D. Qin, G. K. Plattner, M. Tignor, S. K. Allen, J. Boschung, A. Nauels, Y. Xia, V. Bex \& P. M. Midgley (Eds.), Climate Change 2013: The physical science basis. Contribution of working group I to the Fifth Assessment Report of the Intergovernmental Panel on Climate Change (pp. 867-952). Cambridge, U.K. and New York, NY: Cambridge University Press.

Cortés, J. (Ed.) (2008). Investigaciones marinas en la Isla del Coco, Costa Rica / Marine Research at Isla del
Coco (Cocos Island), Costa Rica / Recherches marines à l'Ile du Coco, Costa Rica. Revista de Biología Tropical, 56(Supplement 2), $217 \mathrm{p}$.

Cortés, J. (2012a). Bibliografía anotada sobre organismos, ambientes y procesos marinos en Bahía Culebra, Guanacaste, Costa Rica. Revista de Biología Tropical, 60(Supplement 2), 231-242.

Cortés, J. (2012b). Bibliografía sobre investigaciones marinas, oceanográficas, geológicas y atmosféricas en el Parque Nacional Isla del Coco y aguas adyacentes, Pacífico de Costa Rica. Revista de Biología Tropical, 60(Supplement 3), 363-392.

Cortés, J. (Ed.) (2012c). Investigaciones marinas en el Parque Nacional Isla del Coco, Costa Rica / Marine Research at Isla del Coco National Park, Costa Rica. Revista de Biología Tropical, 60(Supplement 3), $394 \mathrm{p}$.

Cortés, J. (2014). Compilación y análisis de las investigaciones científicas sobre temas marinos y atmosféricos en el Pacífico Norte de Costa Rica. Revista de Biología Tropical, 62(Supplement 4), 151-184.

Cortés, J., Morales, A., Alfaro, E., Lizano, O., \& Acuña, J. (2010). Conocimiento y gestión de medios marinos y coralinos del Área de Conservación Marina Isla del Coco. (Manuales para el monitoreo. Cuadernillo Informativo 2). San José, Costa Rica: SINAC, GEFPNUD y FFMAM.

Enfield, D. B, \& Mestas-Nuñez, A. M. (1999). Multiscale variabilities in global sea surface temperatures and their relationships with tropospheric climate patterns. Journal of Climate, 12, 2719-2733.

Fernández, W. (1984). Comments on meteorological and climatological observations on Coco Island. Revista Geofisica, 20, 9-19.

Fiedler, P. C., \& Lavin-Peregrina, M. F. (2006). Introduction: A review of eastern tropical Pacific oceanography. Progress in Oceanography, 69, 94-100.

Hastenrath, S. (1991). Climate Dynamics of the Tropics. Dordrecht, Netherlands: Kluwer Academic Publishers.

Henderson, S., Rodríguez, A. M., \& McManus, R. (2008). A new future for marine conservation. Eastern Tropical Pacific Seascape. (Technical Document). Virginia, U.S.: Conservation International. Retrieved from http://www.conservation.org/

Herrera, W. (1985). Consideraciones climáticas sobre la Isla del Coco. In W. Herrera (Ed.), Clima de Costa Rica (pp. 40-44). San José, Costa Rica: EUNED.

Hidalgo, H. G. (2013). Tendencias hacia condiciones hidrológicas más secas en Centroamérica (19822005). VII Congreso de la red Latinoamericana de Ciencias Ambientales, San Carlos, Costa Rica.

Huffman, G. J., Adler, R. F., Bolvin, D. T., Gu, G., Nelkin, E. J., Bowman, K. P., Hong, Y., Stocker, E. F., 
\& Wolff, D. B. (2007). The TRMM Multi-satellite precipitation analysis: Quasi-Global, Multi-Year, combined-sensor precipitation estimates at fine scale. Journal of Hydrometeorology, 8, 38-55.

Lavin-Peregrina, M. F., Fiedler, P. C., Amador-Buenrostro, A., Ballance, L., Farber-Lorda, J., \& Mestas-Núñez, A. (2006). A review of the eastern tropical Pacific oceanography: Summary. Progress in Oceanography, 69, 391-398.

Lizano, O., \& Alfaro, E. (2004). Algunas características de las corrientes marinas en Golfo de Nicoya. Revista de Biología Tropical, 52(Supplement 2), 77-94.

Lizano, O. G., \& Alfaro, E. (2014). Dinámica atmosférica y oceánica en algunos sitios del Área de Conservación Guanacaste (ACG), Costa Rica. Revista de Biología Tropical, 62(Supplement 4), 17-31.

Maldonado, T., \& Alfaro, E. (2012). Revisión y comparación de escenarios de Cambio Climático para el Parque Nacional Isla del Coco, Costa Rica. Revista de Biología Tropical, 60(Supplement 3), 83-112.

Mestas-Nuñez, A. M., \& Enfield, D. B. (1999). Rotated global modes of non-ENSO sea surface temperature variability. Journal of Climate, 12, 2734-2746.
Morales-Ramírez, Á, Acuña-González, J., Lizano, O., Alfaro, E., \& Gómez, E. (2015). Rasgos oceanográficos en el Golfo Dulce, Pacífico de Costa Rica: una revisión para la toma de decisiones en conservación marina. Revista de Biología Tropical, 63(Supplement 1): 131-160.

Pittier, H. F. (1898). Apuntamientos preliminares sobre la Isla del Coco, posesión costarricense en el Océano Pacífico. In Reproducciones Cientificas, una Expedición y Legislación de la Isla del Coco, 1963 (pp. 15-28). San José, Costa Rica: Instituto Geográfico de Costa Rica, Ministerio de Transportes.

Protti, M., González, V., Freymuller, J., \& Doelger, S. (2012). Isla del Coco, on Cocos Plate, converges with Isla de San Andrés, on the Caribbean Plate, at $78 \mathrm{~mm} /$ yr. Revista de Biología Tropical, 60(Supplement 3), 3341 .

Quirós-Badilla, E., \& Alfaro, E. (2009). Algunos aspectos relacionados con la variabilidad climática en la Isla del Coco, Costa Rica. Revista de Climatología, 9, 33-44.

Smith, T. M., Reynolds, R. W., Peterson, T. C., \& Lawrimore, J. (2008). Improvements to NOAA's historical merged land-ocean surface temperature analysis (1880-2006). Journal of Climate, 21, 2283-2296. 